\title{
〈Forum·投稿〉
}

\section{ろう者を対象とした新型コロナウィルスに関する インターネット情報の評価とその課題}

\section{インフォデミックの観点から}

\author{
高山 亨太 ${ }^{1, *}$ 皆川 愛 ${ }^{2}$ Poorna KUSHALNAGAR ${ }^{1}$ \\ 1ギャローデット大学 ${ }^{2}$ ギャローデット大学大学院ろう者学修士課程 ${ }^{*}$ Corresponding Author
}

【背景】近年、インターネットやソーシャルメディアは、健康情報を入手するための一手段とな り、かつ多くの人々の健康行動や判断に影響をもたらす情報発信媒体になっている。2019年12月に 初めて感染が確認された新型コロナウィルスは世界的な感染流行となり、それに伴って、科学的根 拠のない不確かな健康情報も爆発的に拡大した。この新型コロナウィルスに関する情報のパンデミ ックが起きている状況を世界保健機関（World Health Organization）は、インフォデミック（Inf odemic）と定義し、注意を喚起している（World Health Organization 2020a）。【目的】本調査 では、日本において緊急事態宣言が発令される2020年3月31日時点での、主にろう者を対象とした新 型コロナウィルスに関する健康情報の実態をインフォデミックの視座から記述統計により分析する ことであった。【方法】インターネット情報検索を行い、ろう者を主な視聴対象とした新型コロナ ウィルスに関する情報サイトやメディアなどの情報発信媒体45件を分析の対象とした。各情報発信 媒体で発信されている健康情報が世界保健機関の推奨寸る感染予防行動基準8項目に準拠している かどうか一致率を検討し、記述統計により分析した。【結果】情報発信源として、聴覚障害者情報 提供施設が23件と最も多かった。世界保健機関の感染予防行動基準にどの程度準拠しているか、総 合平均得点を求めたところ3.24 $(S D=1.93)$ であった。日本手話 $(n=26)$ と日本語 $(n=19)$ の言 語媒体に区分し、比較したところ、統計的に有意な差は見られなかった。日本語を主体とした情報 発信媒体と比較して、日本手話を主体とした情報発信媒体の方が、平均動画再生時間が短く、か つ、字幕などの情報保障をより提供していた。また、一般メディアが取り上げない新型コロナウィ ルスの手話に関する解説や医療手話通訳など、ろう者が必要とする健康情報を独自に発信するなど の取り組みがあった。【考察】調査の結果から、感染予防行動基準を全て満たしている情報発信媒 体は皆無であり、かつ日本手話による情報発信媒体の方が、公的資料を参照したり、監修を受けて いないため、不確かな健康情報を発信している例もあり、それらが結果的にインフォデミックの誘 引要因になり得る可能性が窺われた。今後の課題として、ろう者の健康行動や意思決定におけるイ ンフォデミックの影響について、ろう者を対象にした質的研究や手話動画の内容分析が挙げられ る。

キーワード : 新型コロナウィルス 健康情報 ろう者 日本手話 インフォデミック

\section{1. 問題の所在と目的}

2019年12月に初めて確認された新型コロナウィ ルス(Coronavirus Disease 2019: COVID-19)は、 世界各国での感染拡大が確認され、世界保健機関 (World Health Organization: WHO)がパンデミック
(Pandemic)を宣言する事態となった。

非常事態のみならず平時からろう者は、多くのろ う者にとって言語・コミュニケーション手段である手 話 ${ }^{(1)}$ によって発信されている信頼できる健康情報 へのアクセスが限局され、公平なアクセシビリティの 保障がなされていない実態に直面していることが指

\footnotetext{
1 手話には、伝統的にろう者が自然言語として習得する手話(日本においては、日本手話) と音声言語の構造に合わせて手話の単語を当 てあめた対応手話(日本においては、日本語対応手話)があり、その間のどこかに位置する手話があるとされる(Lucas \& Valli 1989)。ま た、高嶋(2020) は、自然言語としての手話には、都市型手話と地域共有型手話があるとし、壟学校や寄宿舎生活を通して発展した日本 手話は都市型手話であると指摘している。本調査における手話とは、特段の指定がない限り、都市型手話としての日本手話を指してい る。
} 
摘されている(Pollard, Dean, O’Hearn,\& Haynes 2 009; Pollard \& Barnet 2009; McKee \& Paasche-Orl ow 2012; Napier \& Kidd 2013; 皆川 2017)。特に災 害や緊急事態において、万う者はとりわけ健康情報 へのアクセスに制限があるため、健康行動や健康 維持に影響を受けやすいのである(Takayama 201 7）。すなわち、ろう者にとって、健康情報アクセスの 格差は、健康格差につながりうることがこれまでの 研究で指摘されてきた事実であり、ろう者に適した 健康情報アクセスに関寸る喫緊の対策が求められ ている(皆川・八巻・高嶋 2020)。

新型コロナウイルスの症状に関する特徵として、 重症化する感染者から、無症状か軽症のまま完治 する者まで様々な症例が報告されており、無症状 感染者からの感染拡大を予防寸ることが有効な予 防策であり (Bai, Yao, \& Wek 2020; Russel, Hellewe 1l, Jarbis, Van-Zandvoort, Abbot, Ratnayake, Cmm id Covid-Working Group, Flasche, Eggo, Edmunds, \& Kucharski 2020)、そのための適切な健康情報発 信が重要である。また、感染者の同定と隔離による 新型コロナウィルスの封じ込めは困難を極め、集団 免疫を成立させるまでの健康情報発信を含む予防 活動と活動制限が主な医療対策として挙げられて いる(Kissler, Tedijanto, Goldstein, Grad, \& Lipsitc h 2020)。それゆえ、パンデミックにおける急速な感 染流行下では、個々人が最新の健康情報に基づ いて、適切に感染予防行動を実施するともに、地域 全体の爆発的感染を防ぐことが重要である(田辺 2014)。それは、ろうコミュニティにおいても同様であ り、特にパンデミック下での適切な新型コロナウィル スに関する健康情報の確保が極めて重要であるが、 依然として解決されていない課題として指摘されて いる(Paludnevicene, R., Knight, T., Firl, G., Luttr ell, K., Takayama, K., \& Kushalnagar, P. 2020)。

国内では、厚生労働省 (2020)をはじめとして各 地方自治体、医療・研究機関などによって、新型コ ロナウイルスに対する感染予防対策が提示されて いる。これらの健康情報を入手する手段として、テ レビや新聞などのメディア媒体やインターネット、ソ ーシャルメディアが多いのが現実である(高山・八 巻 2016)。しかし、パンデミックなどの災害時には、 ろう者は、音声言語による情報へのアクセスができ ないといら問題に直面しやすく、結果的に災害後の 社会生活に制限が生じやすい(松崎 2013)。東日 本大震災において、健康情報にアクセスできなかっ たろう者は、その後、健康被害や精神的不安に陥り やすいことが指摘されている(Takayama 2017)。

同時に、パンデミックの状況の中、マスメディアや ソーシャルメディアを通じて、科学的根拠にそしい 情報が、急速にかつ大量に拡散し、結果として 個々人の健康行動に影響をもたらしている（近藤 2020)。このような現象について、WHOはインフォ デミックと定義付けて、現代社会の新たな公衆衛生
の問題として指摘している(World Health Organizat ion 2020a)。インフォデミックとは、情報(インフォー メーション, Information) と感染爆発 (エピデミック, e pidemic)を組み合わせた新しい造語である(近藤 2020)。これまでも2010年のチリ大震災、インフルエ ンザ大流行や2011年の東日本大震災、2013年の ボストンマラソンでのテロ事件などの緊急事態にお いて、ソーシャルメディアであるツイッター (Twitter) でインフォデミックそのものが起き、人々の行動に関 する意思決定に大きな影響を与えたことがわかって いる(Starbird, Maddock, Orange, Achterman, \& M ason 2014)。インフォデミックによる影響を受けた 人々の行動の例として、特定の商品の買い占め、 間違った健康情報による健康被害（消毒液を飲め ば、新型コロナウィルスは死滅する、など)が挙げら れる(森・林 2020)。また、パンデミック下の混乱時 に、過半数以上の人々がデマや誤情報などのフェ イクニュースに接したとの報告もある（森・林 2020）。 スペイン語における新型コロナウィルスの健康情報 の信頼性を英語と比較した調査では、調査対象 80 件のうち過半数以上が、マスクの着用の説明がな かったり、WHOの感染予防行動基準を満たしてい なかったりするケースがあった。さらに公衆衛生の 専門機関によって公表された適切な健康情報を参 照している健康情報発信媒体は $34 \%$ みであり、イ ンフォデミックを誘引する要因となった (HernandezGarcia \& Gimenez-Julvez 2020)。また、スペイン語 における新型コロナウィルスに関するインフォデミッ クについて調査したHernandez-Garcia Gimenez-Ju lvez (2020)によれば、ソーシャルメディアや民間機 関による情報提供と比較して、公的機関による情報 発信の方が、新型コロナウィルスに関する健康情報 の妥当性や信頼性が高いことが報告されている。ま た、英語よりスペイン語による情報発信媒体の方が、 スペイン語圈の市民の文化や行動特性に合わせて、 健康情報の内容を工夫し、適切な方法で発信して いるとの結果も報告されている。

著者らがインターネットに掲載されている新型コ ロナウィルスに関する手話動画や文字情報に関す る調査を実施した 2020 年3月 31 日は、日本政府から 新型コロナウイルス感染拡大による緊急事態宣言 が発令される一週間前であり、陽性者数が増加して いるものの、不確かな健康情報によって、3月 20 日 からの三連休では各地でイベントや娛楽施設が再 開され、人出が増えた時期でもあった(厚生労働省 2020)。

そのような状況下で、万う協会や聴覚障害者情報 提供施設などによって、新型コロナウイルス感染症 に関する手話による動画や字幕を付加した情報を インターネット上で公表する例が増えてきた時期で あった。しかし、これらの情報の整合性や信頼性に ついての研究は皆無であり、ろうコミュニティにおけ るインフォデミックの状況の程度を検証することが必 
要である。仮に、ろう者が適切な情報にアクセスで きず、インフォデミックの影響を受けた場合、万う者 は、不適切な健康予防行動を通して、新型コロナウ イルスーの感染リスクに直結する可能性がある(Palu dnevicene, R., Knight, T., Firl, G., Luttrell, K., Ta kayama, K., \& Kushalnagar, P. 2020)。

本調査では、インフォデミックの観点から日本に おける新型コロナウィルスの流行初期に関する情報 発信媒体における使用言語(日本手話および日本 語）の状況と情報保障などのアクセシビリティの様 相を分析することを目的とした。また、WHOの感染 予防行動基準を参照し、発信されている健康情報 の信頼性や整合性について検証し、今後の課題を 明らかにすることも調查目的として設定した。

本調査における仮説は、次の通りに設定した。

(1)音声言語と比較して、日本手話による情報発 信は、アクセシビリティの面で適切な対応が なされている。

(2)日本手話によるろう者を対象とした新型コロナ ウィルスに関する健康情報発信は、WHOの 感染予防行動基準8項目により準拠した対 応がなされている。

\section{2. 方法}

新型コロナウィルスの感染が拡大寸る中、主にろ う者を対象にした新型コロナウィルス感染の予防に 関する健康情報の発信状況や課題を検討寸るため、 Hernandez-Garcia \& Gimenez-Julvez (2020) の研究 方法を参照し、Googleの検索機能を用いてサンプ ルを検出した。インターネット情報検索を 2020 年 3 月 31 日に行った。先行研究の分析枠組みや分析条 件との, 合性を保つ必要性から、ヤフー検索などの 検索機能は調査対象から除外した。検索に用いた キーワードは、「新型コロナウィルス」「手話」「予防」 であった。

上記の方法に従ってキーワード検索を実施した 結果、全国乃うあ連盟や手話通訳団体、聴覚障害 者情報提供施設、ソーシャルメディア(主にフェイス ブックやユーチューブ)を通して発信された新型コ ロナウィルスに関する情報を中心に、約 103 万件の 検索結果が検出された。本調查における分析枠組 みについては、Hernandez-Garcia \& Gimenez-Julv ez (2020)による分析枠組みを参照した。具体的に は、2名の評価者が検索結果の上位 100 件を対象 に、順次に内容を精査し、評価付けを実施した。20 20 年3月 31 日付けで、検索結果に表示されたインタ 一ネット情報を個別に開き、そこから新型コロナウィ ルスの感染予防に関する情報に該当しない55件を 分析対象から除外した上で、45件のインターネット 健康情報を分析対象とした(表1)。

新型コロナウィルスの感染予防に関する情報で あるか否かの判断基準は、2020年3月31日時点で、 WHOが推奨している新型コロナウィルスの感染予
防のための8項目からなる感染予防行動基準 (Worl d Health Organizaton 2020b) 参照した。具体的に は、次の通りである。

(1)適宜、手洗いをする

(2)他者との最低1メートル以上の社会的距離の確保

(3)むやみに目や鼻、口に触れないこと

(4)咳やくしやみの際には咳エチケットを心がけること

(5)体調がすぐれない場合は自宅待機をすること

（6）発熱や咳が悪化し、呼吸困難になった場合、速や かに医師の診断を受けること

（7)咳やくしゃみが見られる場合はマスクを着用すること

（8)新型コロナウィルスに感染した他人を看病する際に は、マスクを着用すること

上記8項目に加えて、厚生労働省 (2020) が公表 している次の3項目も検討項目として追加した。

(9)新型コロナウィルスの症状についての説明

(10)感染経路の説明

(11)感染リスクが高い該当者の説明の有無

また、ろう者に対して手話による新型コロナの説明 を実施しているかどうかも検討するために、次の項 目を独自に追加した。

(12)新型コロナウィルスに関する手話表現の説明

それぞれの項目に該当する健康情報が各メディ アや情報発信媒体に掲載されているかどうかを、2 名の評価者が「該当する」と「該当しない」の二択で 評価した。また、情報発信媒体の使用言語につい て、「日本手話を主体とした情報提供 (日本手話 群)」もしくは「音声言語を主体とした情報提供 (日 本語群)」に分類寸るための評価も実施した。具体 的には、万う者が手話で直接解説している場合に は、日本手話群としてカウントした。一方で、聴者が 音声言語主体で話し、それを受けて、手話通訳者 やろう通訳者が手話に訳している場合には、「日本 語群」として評価した。評価者は、デフファミリー出 身のろう者で、かつ日本手話のネイテイブサイナー である大学院生 2 名に依頼した。評価者 2 名による それぞれの評価の一致度の検討については、Kap pa Indexを採用した。Kapp Indexは、名義尺度での 一致性を検討する際に使用される指標の一つであ り、本調査においては、評価者の主観が入るそれ ぞれの検討項目における判定について、評価者間 で一致するかどうかについて判定するために使用 した。Kappa值が0.80を超え1に近いほど、一致性 が高いとされている(Kundel, H. \& Polansky, M. 20 03）。また、データの分析方法については、記述統 計を基本としながら、調査仮説として設定した日本 手話による情報発信媒体と日本語による情報発信 媒体の差異を確認するために、クロス集計を行い、 カイ二乗検定およびFisher正確検定にて有意差を 
表1 分析対象インターネット一覧 $(n=45)$

\begin{tabular}{|c|c|c|}
\hline 情報発信媒体名 & 区分 & URL \\
\hline 日本手話通訳士協会 & 日本語 & http://www.jasli.jp/pdf/200307corona_taiou.pdf \\
\hline 手話寺小屋 & 手話 & https://www.facebook.com/watch/?v=208005783807578 \\
\hline 明晴学園 & 手話 & $\begin{array}{l}\text { https://www.meiseigakuen.ed.jp/blogs/blog_entries/view/103/02 } \\
\text { 9d796ff5e226dcf76411bfdf77bd60?frame id=215 }\end{array}$ \\
\hline 明晴学園 & 手話 & $\begin{array}{l}\text { https://www.meiseigakuen.ed.jp/blogs/blog_entries/view/103/75 } \\
\text { 1d0ba10c1b0d933b379871c63dac5b?frame id=215 }\end{array}$ \\
\hline 鳥取県聴覚障害者協会 & 手話 & https://torideaf.jp/publics/index/46/ \\
\hline 日本手話研究所 & 手話 & https://www.newsigns.jp/ \\
\hline 神奈川県 & 日本語 & https://www.youtube.com/watch?v=wXFNDwVf87k \\
\hline 横川市 & 手話 & https://www.youtube.com/watch?v=8XKtwk3P7YU \\
\hline 三田市 & 手話 & https://www.youtube.com/watch?v=5ITlbnlpu0w \\
\hline 京都府 & 日本語 & https://www.youtube.com/watch?v=how2ofzNYxc\&feature=youtu.be \\
\hline 京都府 & 手話 & https://www.youtube.com/watch?v=y5EKAFv3xBw\&feature=youtu.be \\
\hline 長野市聴覚障害者センター & 日本語 & $\begin{array}{l}\text { https://deaf-n-n.jimdofree.com/\%E9\%80\%9A\%E8\%A8\%B3\%E6\%B4\% } \\
\text { BE\%E9\%81\%A3\%E3\%81\%AE\%E3\%81\%94\%E6\%A1\%88\%E5\%86\%85/ }\end{array}$ \\
\hline 札幌市 & 日本語 & https://www.city.sapporo.jp/kinkyu_202002.html \\
\hline 広島市ろうあ協会 & 手話 & https://www.hiroshimadeaf.org/ \\
\hline ろう看護師 & 手話 & $\begin{array}{l}\text { https://www.youtube.com/watch?v=PdDvw_axDuQ\&feature=yout } \\
\text { u.be\&fbclid=IwAR3y1rcvyUGzXTCnOm2ThuDCS7OrjqdFWYdEL } \\
\text { li3-g6yywT3lcjBm2hKAAg }\end{array}$ \\
\hline NHK手話ニュース & 手話 & https://www.nhk.or.jp/shuwa/covmov/ \\
\hline NHKハートネット & 日本語 & https://www.nhk.or.jp/heart-net/article/327/ \\
\hline 目で聴くテレビ & 手話 & https://www.youtube.com/watch?v=H1reZH5mO20\&feature=youtu.be \\
\hline 神奈川県聴覚障害者福祉センター & 手話 & https://www.youtube.com/watch?v=K-voXTwiDgU \\
\hline 神奈川県聴覚障害者福祉センター & 手話 & https://www.youtube.com/watch?v=T5h9wP5Z1M8 \\
\hline 神奈川県聴覚障害者福祉センター & 手話 & https://www.youtube.com/watch?v=KSCdd3Q4uUE \\
\hline 長野県聴覚障害者情報センター & 手話 & $\begin{array}{l}\text { https://www.youtube.com/watch?v=fdn_4F8LHOo\&feature=yout } \\
\text { u.be }\end{array}$ \\
\hline 熊本県ろう者福祉協会 & 手話 & https://www.youtube.com/watch?v=6b29ULt-eUs \\
\hline 熊本県ろう者福祉協会 & 手話 & https://www.youtube.com/watch?v=X2NMviWqaRk\&t=2s \\
\hline 熊本県ろう者福祉協会 & 手話 & https://www.youtube.com/watch?v=rKacqlhPV20\&t=16s \\
\hline 横浜市聴覚障害者情報提供施設 & 手話 & https://www.youtube.com/watch?v=sTl3yQYfmPM\&t=11s \\
\hline 横浜市聴覚障害者情報提供施設 & 手話 & https://www.youtube.com/watch?v=Z8oVtABawQY\&t=2s \\
\hline 川崎市 & 日本語 & https://www.youtube.com/watch?v=ISzUH0BwKhE\&feature=youtu.be \\
\hline 東京都聴覚障害者連盟 & 日本語 & https://www.tfd.deaf.tokyo \\
\hline 宮城県聴覚障害者情報センター & 日本語 & http://www.mimisuppo-miyagi.org/singatakoronauirusu.html \\
\hline 沖縄県聴覚障害者情報センター & 日本語 & https://www.otjc.org/news/6167.php \\
\hline あいち聴覚障害者センター & 手話 & https://www.youtube.com/watch?v=6WNluCneYvA\&feature=youtu.be \\
\hline あいち聴覚障害者センター & 手話 & https://www.youtube.com/watch?v=qc9gxdHMPeQ \\
\hline 福井県 & 日本語 & $\begin{array}{l}\text { https://www.pref.fukui.lg.jp/doc/shougai/shougaisyasisaku/koro } \\
\text { natyoukakusyougai.html }\end{array}$ \\
\hline 兵庫県立聴覚障害者情報センター & 手話 & $\begin{array}{l}\text { https://www.youtube.com/watch?v=N3ETocokXY0\&feature=yout } \\
\text { u.be }\end{array}$ \\
\hline 岡山県聴覚障害者センター & 日本語 & http://www.kirameki-plz.com/ 〜 okatyo/ \\
\hline 千葉聴覚障害者センター & 日本語 & http://www.chibadeaf.or.jp/info/i600deaf.html \\
\hline $\begin{array}{l}\text { 名古屋市聴覚言語障害者情報文 } \\
\text { 化センター }\end{array}$ & 日本語 & http://meishinren.or.jp/modules/info/index.php?action=PageView\&page_id=20 \\
\hline 富山県聴覚障害者情報センター & 日本語 & http://www.tomichokyo.or.jp/ \\
\hline 山梨県 & 日本語 & https://www.youtube.com/watch?v=pQ6o4gILVQg\&feature=youtu.be \\
\hline 東京都 & 日本語 & https://www.youtube.com/watch?v=sNsXpkD3zEY\&feature=emb_rel_end \\
\hline 大阪聴力障害者協会 & 日本語 & http://daicyokyo.jp/ \\
\hline NPO法人MAMIE & 手話 & $\begin{array}{l}\text { https://www.youtube.com/watch?v=v7ihPCj6fww\&feature=youtu. } \\
\text { be\&fbclid=IwAR1fYYME47doWwpLFH8Xu296dYLjlPmH4KWURn } \\
\text { 5S64IdWxhZb6mbCoX7M_0 }\end{array}$ \\
\hline 近畿大学医 & 日子 & https://www.youtube.com/watch?v=mobPCLkKPTU \\
\hline 静岡県 & 手話 & https://www.youtube.com/watch?v=LPrcaQNxWHc \\
\hline
\end{tabular}


検討した。また、感染予防行動基準に準拠している 項目を得点化し、t検定にて平均值の比較を行った。 得点化の手順については、上記に挙げたWHOの 感染予防行動基準8項目について、情報発信媒体 の中で説明があった場合に、1とし、一方で、説明 がなかった場合や不明な場合には0として処理した。 8項目の合計で得点を算出した。得点数は、0点か ら8点まであった。これらの分析の際には、SPSS Sta tistics ver.25を使用した。

\section{3. 結果}

Google検索の結果、新型コロナウィルス感染予 防に直接関係のない情報発信であるため研究対象 として該当しなかった55件を除外し、最終的に45件 を分析対象とした(表1)。

まず、2名のろう者による評価者による45件の情 報発信媒体における世界保健機関の感染予防行 動基準の8項目の評価点数および使用言語媒体に ついてKappa Indexに基づいて、評価の一致性を確 認したところ不一致点は見られなかった（Kappa=1）。 45件のインターネット基本情報は、表2に示した 通りである。45件のうち、26件 (58\%) は、日本手話を 主な使用言語として情報発信を行っており(日本手 話群）、19件が日本語を主な使用言語としていた (日本語群)。情報発信者については、聴覚障害者 情報提供施設が23件 (51\%) と最も多く、次いで、ろ う協会の8件 (18\%) であった。図1の通り、情報発信 媒体については、日本手話群の場合は、手話動画 との親和性の高いューチューブなどのソーシャルメ ディアを利用した情報発信 $(n=25)$ が多い一方で、 日本語群は団体の公式ウェブサイトを通しての情 報発信が多く見られ $(n=14)$ 、有意差が見られた。

なお、情報保障に関しては、日本手話群のうち、 26件中17件が字幕などの情報保障によるアクセシ ビリティを確保しているのに対して、日本語群にお いては、19件のうち4件 (21\%)しか字幕や手話通訳 による情報保障を提供していなかった(図2)。

また、厚生労働省やWHOなどの公的機関が公 表した科学的情報に基づいて、新型コロナウィルス に関する健康情報が掲載されているかどうかにつ いては、日本手話群が26件中 15 件 (58\%)であるの

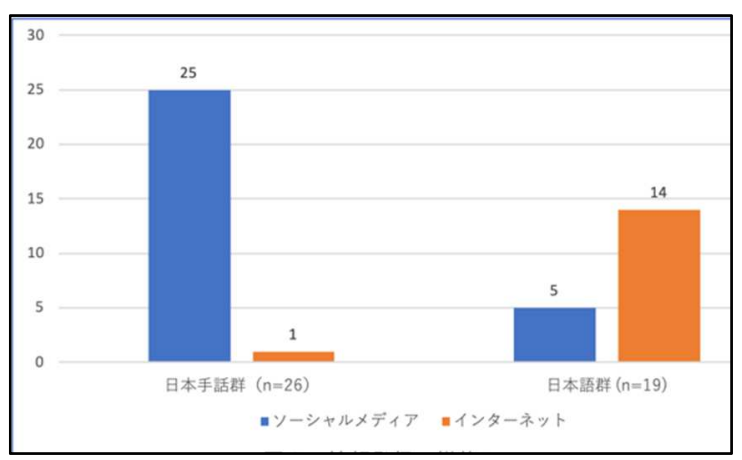

図1 情報発信の媒体について
に対して、日本語群の場合には、19件中8件 (42\%) と割合がやや低かった。手話動画の掲載有無につ いては、全ての日本手話群の情報発信媒体が手話 動画を掲載している一方で、日本語群では、8件 (4 $2 \%)$ のみ゙あった。具体的は、日本語群16件のうち 手話通訳が8件 $(42 \%) 、$ 字幕が4件 (23\%)であった。 なお、それぞれの手話動画の時間 (分) は、日本手 話群が平均4.25 ( $S D=2.44) 、 日$ 本語群が平均7.51 $(S D=6.36)$ であり、有意差が見られた $(t=-2.27, d f=3$ $2, p<.05)$ 。動画自体の再生時間で最も長かったの が16分52秒であった。一方で、最も再生時間が短 かったのが1分 16 秒であつた。なお、動画を掲載し たソーシャルメディア媒体で最も多かったのが、ユ 一チューブであり、日本手話群で 26 件中 15 件 (57.6 9\%) と過半数を超えている一方で、日本語群におい ては19件中5件 (26\%)のみあった。2020年3月31日 時点での視聴数については、日本手話群のユーチ ユーブでは平均6578の視聴者数であるのに対して、 日本語群では平均1217という結果であった。

次に、WHOが公表している感染予防行動基準に ついて、日本手話群と日本語群を合わせた総合平 均得点は3.24 $(S D=1.93)$ であった。各情報発信媒体 がWHOの感染予防行動基準に準じているかどうか について検定にて検討したところ、8項目全てにお いて、日本手話群と日本語群の間に有意差は検出 されなかった（表3）。また、感染予防行動基準につ いて、日本手話群の情報発信媒体の総合平均得 点 $(M=3.08, S D=2.07)$ と日本語群の情報発信媒体 の総合平均得点 $(M=3.47, S D=1.74)$ の間において も統計的有意差は検出されなかった $(t=-.676, d f 42$. 09, $p=$.491)。日本手話群の方が日本語群と比較し て、より公的発表資料を参照にして情報発信をして いる割合が高い一方で、日本語群の方が若干、W HOの感染予防行動基準の準拠率が高い傾向があ った。

なお、8項目全てを満たした情報発信媒体は一つ も該当しなかった。さらに、日本手話群では26件中 5件が一つもWHOの感染予防行動基準を満たして いなかった。WHOの感染予防行動基準8項目のう ち準拠されている割合が高かった項目順として、(1) 適宜、手洗いをする $(n=28,73.3 \%) 、(7)$ 咳やくしやみ が見られる場合は、マスクを着用すること $(n=26,5$

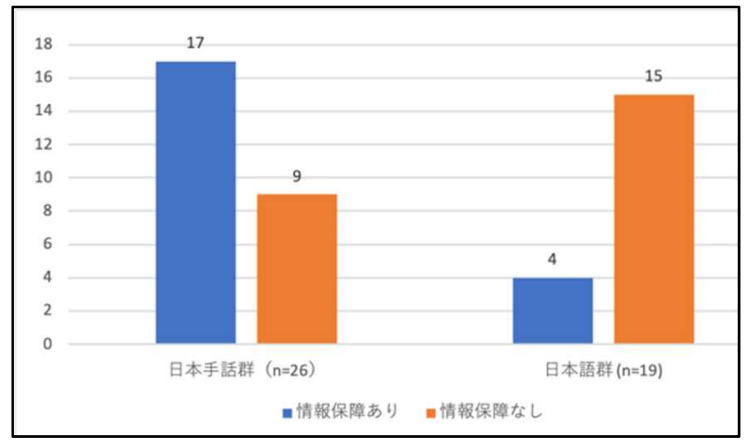

図2 情報保障の有無 
8\%)、そして、(2)他者との最低1.8メートル以上の社 会的距離の確保、ならびに(7)咳やくしやみが見ら れる場合は、マスクを着用すること $(n=25,56 \%)$ の順 に多かった。もつとも少なかった順に、（8)新型コロ ナウィルスに感染した他人を看病する際には、マス クを着用すること $(n=1,2 \%)$ 、次いで、(3)むやみに目 や鼻、口に触れないこと $(n=4,9 \%) 、(5)$ 体調がすぐ

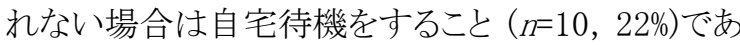
った。一方で、WHOの感染予防行動基準として記 載されていないその他の基準として、(9)新型コロナ ウィルスの症状に関する説明が 20 件(44\%)と多く、 次いで、(12)感染リスクが高い該当者の説明の有無 が18件 (40\%)であった。また、その他の説明として、 部屋の換気を推奨する説明が 14 件 $(31 \%)$ 、医療機 関にかかる時の医療通訳者の依頼方法について

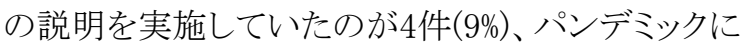
関する手話表現及び意味の説明をしている情報発 信媒体は、45件中 2 件 $(4 \%)$ が該当した。

\section{4. 考察}

本調査の目的は、日本が緊急事態宣言を発する 前のパンデミックの状況の中で、新型コロナウィルス に関する健康情報発信における、各種情報発信媒

表2 各インターネット情報の基本情報 $(n=45)$ 単位 $n(\%)$

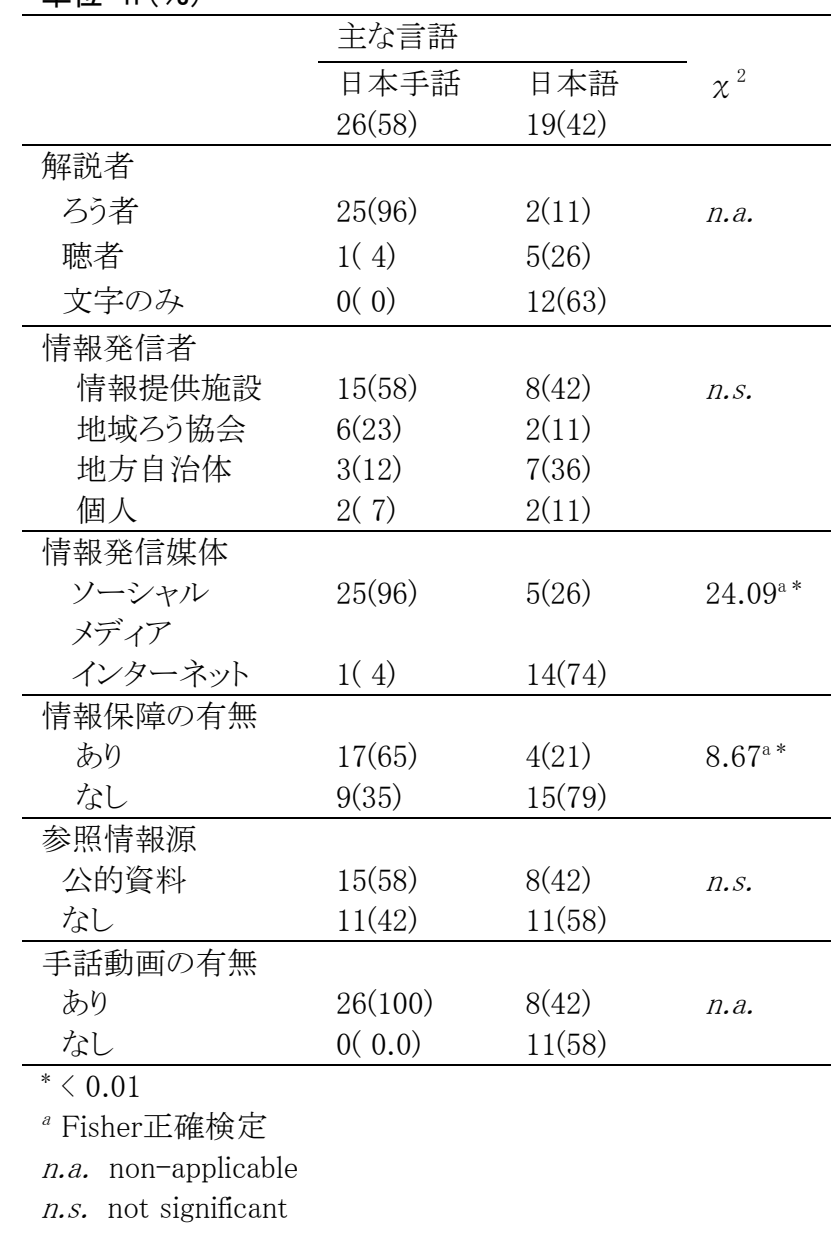

体における使用言語 (日本手話および日本語) と字 幕や手話通訳などのアクセシビリティを明らかにし、 また、WHOの感染予防行動基準から、それらの健 康情報の信頼性やインフォデミックの程度について 記述統計の観点から検証することであつた。調査対 象45件中、WHOの感染予防行動基準8項目全てを 満たしている情報発信媒体は、一つも該当しなかっ

\section{表3 各種インターネット情報のWHO感染予防行動 基準準拠に関する評価 $(n=45)$}

単位 $\mathrm{n}(\%)$

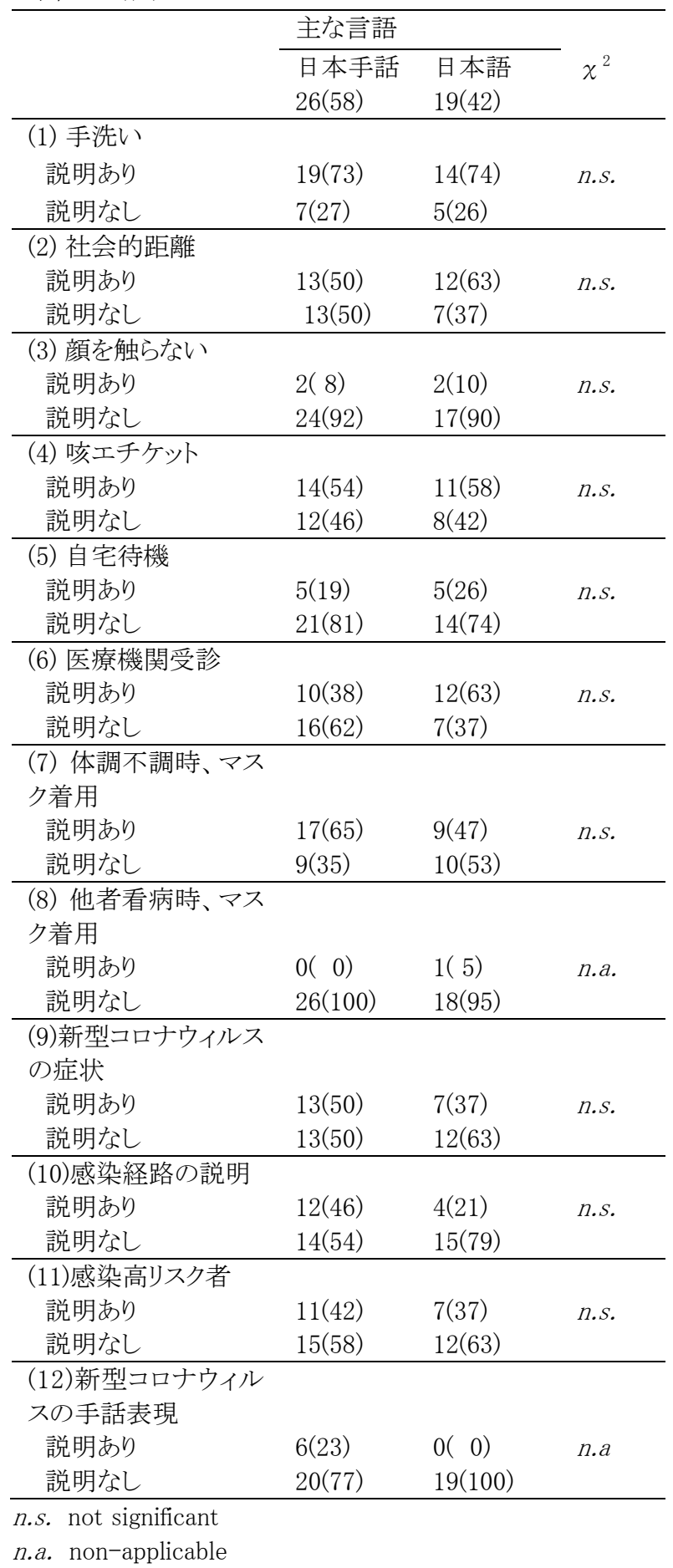


たが、約半数の $47 \%$ が 8 項目のうち4 項目以上の基 準を満たしていた。日本手話群と日本語群ともに最 も多かった項目は、「(1)手洗い」、であったが、二 番目以降は、それぞれ異なる項目が検出された。 日本手話群は、「(7) 体調不調時にマスク着用」 「(4)咳エチケット」の順に多かったが、日本語群は、 $「(2)$ 社会的距離」「(6) 医療機関受診」であった。

一方で、一つも基準を満たしていない情報発信 媒体が日本手話群で5件もあり、健康情報の信頼 性が疑われる情報源も検出された。例えば、地域 福祉を支える専門機関である聴覚障害者情報提供 施設としての情報発信であるにも関わらず、情報の 引用元を明記せず、解説者個人の主観に基づい た不確かな情報を提供している例が3件も検出され た。これらの多くは公衆衛生を担う専門機関による 健康情報発信ではない場合が多く、Hernandez-Ga rcia \& Gimenez-Julvez (2020)の調查結果と同様で あった。また、地方自治体や厚生労働省などの行 政による情報発信と比較して、民間団体である地域 ろう協会や聴覚障害者情報提供施設は、適切な健 康情報発信の研修や専門家による監修を受けてい ない状況が窥える。そのため、情報発信を担う機関 に属する個々人が既存の情報を取捨選択し、任意 的に発信しているものが多数であり、ろう者を対象と した公衆衛生策として有益な情報源になりうるかに ついて疑問が残る点は否めない。また、行政や研 究機関などが発表した情報を参照せずに、個人の 判断で不適切な情報発信をしている場合、デマや 間違った健康情報の流布しやすいろうコミュニティ においては、インフォデミックを誘引しやすい要因と なり得る。

また、厚生労働省公表の3項目において、日本 手話群と日本語群で差が窥われた。具体的には、 日本語群と比較して、日本手話群の方がより多く厚 生労働省の3項目を取り上げて情報発信をしていた。 また、新型コロナウィルスに関する手話表現につい て、日本語群が19件中1件も発信していないのに対 して、日本手話群は、少数であるが19件中 6 件が手 話表現の説明および啓発を実施していた。このよう に、日本手話群においては、WHOの感染予防行 動基準とは別に、新型コロナウィルスに関する各種 症状や感染リスク、新型コロナウィルスに関する手 話表現の説明など、健康情報アクセスに困難を抱 えやすいろう者の状況を鑑みた健康情報発信がそ れぞれの情報発信媒体の判断で追加されたものも 多く見られた。厚生労働省などの公衆衛生機関の 情報を参照、さらに監修を受けることによって、適切 な情報を作成し、信頼性を高める取り組みが重要 であり、今後の課題として挙げられる。

字幕や手話通訳などのアクセシビリティの有無に ついては、日本語群 $(n=4,21 \%)$ と比較して、日本手 話群 $(n=17,65 \%)$ の方が字幕などの情報保障を提 供している割合が高く、有意差がみられた。地方自
治体による情報発信媒体において散見されたが、 手話による動画の提供はなく文字のみしかアクセス できない例や、地方自治体首長が出演し、音声日 本語による情報発信が主体となっているが、これは、 ろう者や情報弱者にとって、健康行動を左右寸る健 康情報にアクセスしにくいといら格差を生む構造と なっている。つまり、動画そのものにアクセシビリティ が配慮されておらず、資料のみしか文字情報にア クセスできない例まであった。そのため、地方自治 体による音声言語主体での情報発信においては、 特に字幕や手話通訳の配置などのアクセシビリティ の向上が課題であり、それらを改善する方策の一 つとして、地域のろう当事者の参画、地域の手話に 関する政策立案の強化などが必要であると考えら れる。

本調査の限界として、Hernandez-Garcia \& Gimen ez-Julvez (2020)の分析手順を参照したが、手話と 音声言語の違いや参照サンプルが少ないこと、ま たインターネット上の情報のみに焦点を当てたため、 今回の調查手順や結果をろうコミュニティにおける インフォデミックの評価やパンデミック下におけるろ う者の健康情報の評価として、本結果を全面的に 適応寸ることには限界がある。また、日本手話と日 本語対応手話を、それぞれ厳密に定義した上で、 手話動画の種類をさらに区分し、情報発信の内容 について検討していないため、今後の研究課題とし て残っている。

今後の研究課題としては、手話動画のろう者への 有用可能性について、様々な背景をもつろう者によ る評価検証、またインフォデミックによるろう者の健 康行動への影響に関する調査が必要である。さら に感染症拡大時などの緊急時に備え、公衆衛生に 関する手話動画作成の手順の基準の検討も課題と してあげられる。

\section{参考文献}

Bai, Y., Yao, L., \& Wek, T. (2020). Presumed asym ptomatic carrier transmission of COVID-19. Jo urnal of American Medicine Association, 323(1 4), 1406-1407. doi:10.1001/jama.2020.2565

Hernandez-Garcia, I \& Gimenez-Julvez, T. (2020). Assessment of health information about COVID -19 prevention on the internet: Infodemiological study. JMIR Public Health and Surveillance, 6 (2), 1-11.

Kissler, S. M., Tedijanto, C., Goldstein, E., Grad, Y. H., \& Lipsitch, M. (2020). Projecting the tra nsmission dynamics of SARS-CoV-2 through th e postpandemic period. Science, 268(6493), 860 $-868$.

Kundel, H. \& Plansky, M. (2003). Measurement of observer agreement. Radiology, 228(2), 203-30 8. 
Lucas, C.\& Calli, C. (1989). Language Contact in t he America Deaf Community, Lucas, C. ed, The Sociolinguistics of Deaf Community, Academic, 11-40.

近藤誠司 (2020)『COVID-19 インフォデミックの諸 相』社会安全学研究, 11, 1-13.

厚生労働省 (2020)『新型コロナウイルス感染症に ついて』厚生労働省, https://www.mhlw.go.jp/s $\mathrm{tf} /$ seisakunitsuite/bunya/kenkou_iryou/dengue_ fever_qa_00001.html, (参照 2020-04-15).

Mandoza, M., Poblete, B., \& Castillo. (2010). Twitt er under crisis: Can we trust what we rt? SOM A, 10, 71-79. doi 10.1145/1964858.1964869

松崎丈(2013)『東日本大震災で被災した聴覚障害 者における問題状況一情報アクセスの視点から 一』宮城教育大学特別支援教育総合研究セン タ一研究紀要, 8, 15-32

McKee, M. M., \& Paasche-Orlow, M. K. (2012). H ealth literacy and the disenfranchised: The impo rtance of collaboration between limited English proficiency and health literacy researchers. Jour nal of Health Communication, 17(Suppl. 3), 7- 1 2. doi:10.1080/10810730.2012.712627

皆川愛 (2017)『日本における文化言語的マイノリテ イとしてのろう者が医療を受ける体験』聖路加国 際大学大学院修士論文.

皆川愛・八巻知香子・高嶋由布子 (2020)『言語的 マイノリティしてのろう者を対象にした手話版 大腸がん資料の作成』第12回日本ヘルスコミュ ニケーション学会学術集会,帝京大学.

森健・林裕之 (2020)『新型コロナウィルス感染拡大 下の日本人の情報収集行動〜デジタル空間で の「インフォデミック」抑止にも注力を〜』野村総 合研究所.

Napier, J., \& Kidd, M. R. (2013). English literacy a $\mathrm{s}$ a barrier to health care information for deaf pe ople who use Auslan. Australian Family Physicia n, 42, 896-899.

Pollard, R. Q., \& Barnett, S. (2009). Health-relate d vocabulary knowledge among deaf adults. Reh abilitation Psychology, 54(2), 182-185. doi: 10. 1037/a0015771

Pollard, R. Q., Dean, R. K., O’Hearn, A., \& Hayn es, S. L. (2009). Adapting health education mat erial for deaf audiences. Rehabilitation Psycholo gy, 54, 232-238. doi:10.1037/a0015772

Paludnevicene, R., Knight, T., Firl, G., Luttrell, K., Takayama, K., \& Kushalnagar, P. (2020). Perce ption and misinformation during the COVID-19 pandemic: A cross setional survey of deaf and $h$ ard of hearing adults in U.S.. Journal of Medical Internet Research, 22(11) 1-20.

Russell, T. W., Hellewell, J., Jarvis, C. I., van Zand voort, K., Abbott, S., Ratnayake, R., Cmmid C ovid-Working Group, Flasche, S., Eggo, R. M., Edmunds, W. J., \& Kucharski, A. J. (2020). Esti mating the infection and case fatality ratio for $\mathrm{c}$ oronavirus disease (COVID-19) using age-adjus ted data from the outbreak on the Diamond Prin cess cruise ship, February 2020. Euro surveillan ce : bulletin Europeen sur les maladies transmis sibles = European communicable disease bulleti n, 25(12), 2000256. https://doi.org/10.2807/1 560-7917.ES.2020.25.12.2000256

Starbird, K., Maddock, J., Orange, M., Achterman, P., \& Mason, R. M. (2014). Rumors, false flags, and digital vigilantes: misinformation on Twitter after the 2013 Boston Marathon Bombing. iCon ference 2014. doi 10.9776/14308

高嶋由布子 (2020)『危機言語としての日本手話』 国立国語研究所論集18, 121-148.

Takayama, K. (2017). Disaster relief and crisis inte rvention with deaf communities: Lessons learne $\mathrm{d}$ from the Japanese deaf community. Journal of Social Work in Disability \& Rehabilitation, 16(3), 247-260.

高山智子・八巻知香子 $(2016)$ 『必要とする人により 効果的に健康関連情報を届けるために一人々 の情報探索行動の特徽からの検討一』保健医 療社会学論集, 27(1), 39-50.

田辺正樹 (2014)『感染症パンデミック時の対応』日 内会誌, 103, 2461-2769.

World Health Organization. (2020a). Novel coronav irus (2019-nCOV) situation report-13. Retrieve d from https://www.who.int/docs/default-sourc e/coronaviruse/situation-reports/20200202-sit rep-13-ncov-v3.pdf?sfvrsn=195f4010_6

World Health Organization. (2020b). Coronavirus d isease 2019 (COVID-19) situation report -85. R etireived from https://www.who.int/docs/defaul $\mathrm{t}$-source/coronaviruse/situation-reports/2020 0415- sitrep-86- covid -19 .pdf?sfvrsn=c615ea20_ 4 
〈Forum〉

\title{
Assessment of Internet Health Information on the COVID-19 among Deaf Communities in Japan: From Infodemiological Perspective
}

\author{
TAKAYAMA Kota $1, *$, MINAKAWA Ai 2, and KUSHALNAGAR POORNA 1 \\ 1 Gallaudet University, 2 Master's Program in Deaf Studies at Gallaudet University, * Corresponding author
}

Background: The Internet and social media have rapidly become a large source of COVID-19 information $\mathrm{f}$ or people including those who are deaf and use Japanese Sign Language. COVID-19 information deployed t hrough the Internet and social media has the potential to influence people's health-related decision makin g (e.g. physical distancing; staying in quarantine after travel). After the World Health Organization (WHO) declared the COVID-19 situation as a global pandemic, some of the COVID-19 information lacked scientif ic evidence which increases misinformation. When the misinformation is abundant and rapidly spread on the Internet, this is described as Infodemic. Strategies to reduce Infodemic include correcting misinformation a nd rumors related to the spread of the coronavirus. Objective: To identify COVID-19 information sources in Japanese Sign Language and examine. Methods: On March 31, 2020, we performed Google Search with k eywords: "Novel coronavirus," "Prevention," and "Sign language". A descriptive statistical analysis was c onducted to describe the association between the World Health Organization's eight preventive recommen dations and COVID-19 information sources, including JSL videos, that are targeted for the Japanese deaf c ommunity. Results: A total of 45 websites and social media accounts were reviewed for inclusion of JSL vid eos about COVID-19. Out of 45 websites and SM accounts, 23 videos were developed by the local deaf inf ormation and cultural support centers. Most of these 23 video-based information sources did not follow th e World Health Organization's eight preventive recommendations; thus, the credibility and reliability of C OVID-19 in JSL were lower and uncertain. However, videos produced by the deaf organizations included e xplanations of COVID-19 symptoms and provided greater accessibility to COVID-19 information than the hearing centered organizations. Conclusions: Infodemic issues are largely affected by low quality of COVID -19 informtion. Consultation with health professionals who are fluent in Japanese Sign Language is required to ensure that COVID-19 sources in JSL are of high quality and promote deaf people's health behavior an $\mathrm{d}$ knowledge about the coronavirus.

Key words: COVID-19, Health Information, Deaf, Japanese Sign Language, Infordemic 